\title{
Az emberi csípő, térd és gerinc biomechanikai jellemzői, valamint terhelés hatására létrejött elváltozásainak áttekintő elemzése
}

\section{1. rész: A csípöízület biomechanikája}

\section{An Overview of the Biomechanical Characteristics of the Human Hip, Knee and Spine, as well as the Changes Caused by Exercise}

\section{Part 1: Biomechanics of the Hip Joint}

Tanulmányomban, amely egy szélesebb kutatás része, a haderö aktív állományának mozgásszervi terhelését és az annak következtében kialakuló panaszokat vizsgálom, a nemzetközi szakirodalomban fellelhető hasonló kutatások áttekintésével. Cikksorozatom első része a csípőizülettel, annak biomechanikai összefüggéseivel, a terhelés következtében fellépő eröhatásokkal és azok következményeivel foglalkozik. A csípőben kialakuló terhelési viszonyok bemutatásával látható, hogy még egészséges, normál anatómiájú csípő esetén is jelentős terhelés esik az ízület porcára. A túlterheléssel, az ízület anatómiai eltéréseinek következtében vagy ezek együttes hatására a panaszok nagyobb valószínüséggel alakulnak ki.

Kulcsszavak: csípőízület, biomechanika, túlterhelés, anatómia, haderő, katonaság In my study, I examine the musculoskeletal loading and subsequent complaints of the active members of the armed forces by reviewing similar studies in the international literature. The first part of my series of articles describes the hip joint, its 
biomechanical relationships, the forces developing due to loading and their consequences. By presenting the loading conditions in the hip joint, it can be seen that even in the case of a healthy hip joint with normal anatomy, a significant load falls on the cartilage of the joint. In case of overload, due to anatomical abnormalities in the joint or due to their additive effect, complaints are more likely to develop.

Keywords: hip joint, biomechanics, overload, anatomy, force, military

\section{Bevezetés}

Doktori kutatásom az aktív katonai állomány tagjai közt megjelenő mozgásszervi problémákat vizsgálja. E kutatás részeredményeit szeretném megosztani jelen cikkemben, amely a csípőizület túlterhelésével járó következményeket elemzi, egy szélesebb spektrumú irodalmi szemlézés formájában. Írásomban a csípőízületünk anatómiai, biomechanikai jellemzőit is bemutatom, amelyek megértésével nyilvánvalóvá válik az ízület túlterhelésének problémája, azonban hangsúlyozni szeretném, hogy e fejezetekben csak az elengedhetetlenül szükségesnek ítélt anatómiai és biomechanikai információkat taglalom. Jelen írásom nem ezen összefüggések részletes felfedését hivatott elvégezni, azonban a továbbiak megértéséhez, illetve az összefüggések megfelelő módon történő átlátásához, valamint a következtetések elfogadásához elengedhetetlen bizonyos ismeretek megléte. Szintén nem cikkem tárgyköre a csípőízületet érintő betegségek széles körü bemutatása, azonban néhányról említést kívánok tenni, valamint a kutatásom egyik hipotézisét ${ }^{2}$ érintő betegségről, a csípőizületi beütődéses kórképről kissé részletesebben is szeretnék információt közölni, irodalmi utalásokkal alátámasztva fontosságát.

\section{A csípőízület anatómiája}

A csípőízület (articulatio coxae) gömb vagy szabad ízületnek nevezett biomechanikai és anatómiai egység. Csontosan az ízvápa (acetabulum) és ízfej (caputfemoris) alkotja. Az ízvápa porca egy $C$ alakú területen helyezkedik el, míg az ízfej nagy része porccal fedett. Az ízvápa szélét egy 5-6 mm vastag, rostos porc gyúrü, a labrum acetabuli veszi körül, amelynek a későbbiek taglalásánál látjuk jelentőségét. Az ízület érdekessége, hogy a fej mindennemű szalag és egyéb rögzítés nélkül is bent marad a vápában. Természetesen ízületi tokkal rendelkezik, mint minden ízület, amelyet szalagok borítanak. Ezekből hármat ismerünk: ligamentum iliofemorale, amely egyébként a test legerősebb szalagja, ligamentum pubofemorale és ligamentum ischiofemorale. Érdekességük, hogy mind a három szalag elölről le felé és hátulról felfelé csavarodik a combcsont nyakára.

Kutatásom egyik hipotézise: „Feltételezem, hogy a csípőízület degeneratív megbetegedése - hasonlóan, a többi degeneratív megbetegedésekhez - nagyobb valószínűséggel jelenik meg az aktív, szolgálatot teljesítő állomány körében." 
A negyedik szalag az ízületen belül elhelyezkedő ligamentum capitis femoris, amelynek jelentősége - az élet egy szakaszán - a vérellátásban keresendő. ${ }^{3}$

A csípő mozgását az 1. táblázatban feltüntetett izmok végzik.

1. táblázat

A csípő mozgatását végző izmok

Forrás: a szerző szerkesztése

\begin{tabular}{|l|l|l|}
\hline Belső csípőizmok & Külső csípöizmok & $\begin{array}{l}\text { A comb közelítő izmai } \\
\text { (adductorok) }\end{array}$ \\
\hline musculus iliopsoas & musculus gluteus maximus & musculus pectineus \\
\hline musculus piriformis & musculus gluteus medius & musculus adductor longus \\
\hline $\begin{array}{l}\text { musculus obturator } \\
\text { internus }\end{array}$ & musculus gluteus minimus & musculus adductor brevis \\
\hline & musculus tensor fascia latae & musculus gracilis \\
\hline & musculus quadratus femoris & musculus adductor magnus \\
\hline & musculus obturator externus & \\
\hline & musculus gemellus superior & \\
\hline & musculus gemellus inferior & \\
\hline
\end{tabular}

A csípő biomechanikai elemzéséhez elsőként érdemes megismerkedni pár fogalommal annak érdekében, hogy értelmezni tudjuk az ízület mozgását és meg tudjuk ítélni, érteni a normálistól eltérő, kóros mozgások jelentőségét, illetve az abból eredő hátrányokat.

Konstrukciós tengely: A combfej középpontja és a felső ugróízület belső egyharmadát jelölő pontot összekötő tengely, amelynek közbeiktatott pontja a térdkalács ín tapadási területe. (tuberositas tibiae)

Rotacio: forgómozgás

Abductio: a test középvonalától elfelé tartó mozgás

Adductio: a test középvonala felé tartó mozgás

Flexio: hajlító mozgás

Extensio: feszítő mozgás

Circumductio: a csípőízületben meglévő mozgások, egymással kombinált, kúppalástot leíró mozgásformája

Sagittalis: nyílirányú

Collodiaphysealis szög: a combcsont teste és nyaka közti szög. ${ }^{4}$ Az életkor elörehaladtával változik. Felnőtt korban jellemzően $135^{\circ}$, de idős korra $120^{\circ}$-ra lecsökken. ${ }^{5}$

3 Szentágothai János - Réthelyi Miklós: Funkcionális anatómia. 1. kötet. Budapest, Medicina-Semmelweis, 1996. 365-366.

4 A collodyaphysealis szög (CD szög) az életkor változásával alakul ki. Felnőtt korra jellemző értéke kb. 135-138². Idős korra $120^{\circ}$-ra csökken. A CD szög normálistól való eltérése, kisebb (coxa vara) vagy nagyobb (coxa valga) mértékben jelentősen megváltoztatja a csípőízület biomechanikáját, ezáltal a degeneratív betegségek kialakulását fokozza.

5 Szendrői Miklós (szerk.): Ortopédia. Budapest, Semmelweis, 2005. 342. 


\section{A csípőízület biomechanikája}

A combfejek középpontját összekötö haránttengely körül valósulnak meg csípőnk mozgásai: a hajlítás (flexio) és nyújtás (extensio), a nyilirányú (sagittalis) tengely körül a távolítás (abductio) és a közelítés (adductio), a konstrukciós tengely körül a csavarodó mozgás ( $k i-$, és berotatio). A normál mozgástartományokat a 2. táblázatban foglaltam össze.

2. táblázat

A csípőízület normál mozgástartományai

Forrás: a szerző szerkesztése Szendrői (szerk.) (2005): i. m. 342. alapján

\begin{tabular}{|l|l|}
\hline flexio & $0^{\circ}-130^{\circ} / 140^{\circ}$ \\
\hline extensio & $0^{\circ}-10^{\circ}$ \\
\hline abductio nyújtott csípónél & $0^{\circ}-30^{\circ} / 45^{\circ}$ \\
\hline abductio 90 fokban hajlított csípőnél & $0^{\circ}-80^{\circ}$ \\
\hline adductio & $0^{\circ}-20^{\circ} / 30^{\circ}$ \\
\hline kifelé rotatio nyújtott csípőnél & $0^{\circ}-30^{\circ} / 40^{\circ}$ \\
\hline kifelé rotatio 90 fokban hajlított csípőnél & $0^{\circ}-40^{\circ} / 50^{\circ}$ \\
\hline befelé rotatio nyújtott csípőnél & $0^{\circ}-40^{\circ} / 50^{\circ}$ \\
\hline befelé rotatio 90 fokban hajlított csípőnél & $0^{\circ}-30^{\circ} / 45^{\circ}$ \\
\hline
\end{tabular}

A csípőizületre ható erőket a pauwelsi ${ }^{6}$ biomechanikai rendszer szemlélteti, amit az 1. ábrán mutatok be.

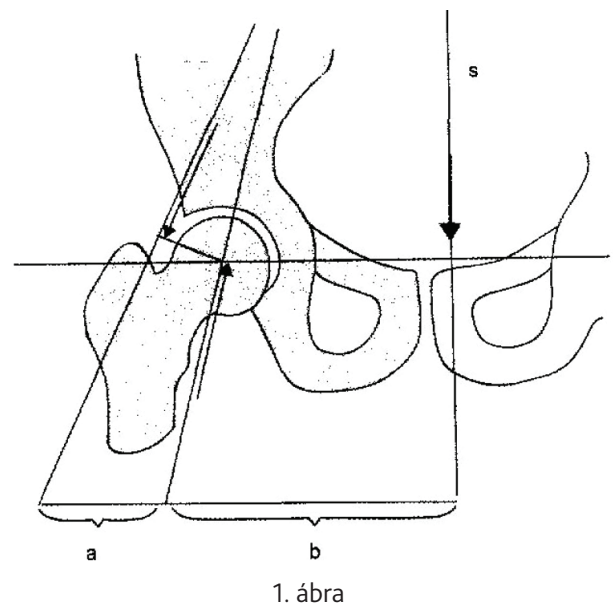

Normális collodiaphysealis szög esetén a teher- és az erökararány Forrás: Szendrői (szerk.) (2005): i. m. 343.

a: erőkar; b: teherkar S: súlyvonal. A normál CD szöghöz tartozó teherkar- és erőkararány: 3 : 1 (b: a).

6 Friedrich Pauwels (1885-1980): a német biomechanika egyik legnagyobb alakja. Munkássága jelentőségét bizonyítja, hogy elnyerte az ortopédia tiszteletbeli professzora címet is. Munkája nagy mértékben hatással volt a modern biomechanikai szemléletek kialakulására. 
Tulajdonképpen a fentebb említett mozgásokból adódik össze csípőízületünk helyváltoztató mozgáshoz szükséges komplex működése, amelynek következtében, állás, járás, ugrás és futás tevékenységek váltogatásával érjük el azt, hogy képesek vagyunk eljutni „A” pontból „B” pontba. Az állás és járás az emberi élet minden területén fontos tevékenység, amit koordinált, mozgásszervileg bonyolult izomműködéssel és biomechanikával jellemezhető módon végzünk mindennapjainkban. Bár maga az állás és járás folyamata egyáltalán nem írható le könnyen biomechanikailag, mégis, bizonyos értelemben egyfajta alapfunkcióként tekinthetünk erre a két tevékenységre.

Vizsgáljuk is meg kicsit részletesebben ezeket. A csípőízület mozgása közben, az alsó végtagokat feloszthatjuk egy támaszkodó és egy lengő végtagra, amely végtagok változó szerepben biztosítják haladásunkat. Amíg a lengőoldali végtag ebben a fázisban van, addig a teljes terhelés a támaszkodó végtagra esik, elviselve a gravitációs erő hatását, a törzs súlyát. A lendítő oldali medencefél lebillenését a csípőízület abductor izomzata biztosítja, ez később fontos összefüggéseket tár fel a térdízületünk vonatkozásában is, illetve a gerinc biomechanikájában is változást okoz egy, a csípő abductor izomzatát érintő izomgyengeség. Csípőnk a kétkarú emelő elve alapján müködik, ahol az egyensúlyi helyzetben az

$$
\text { erő } \times \text { erőkar }=\text { teher } \times \text { teherkar }
$$

egyenlet érvényesül. Az erőkar (a) a csípőközpont és az egyensúlyi helyzetet létrehozó abductorok erővektorának vízszintesre vetített távolsága, a teherkar (b) pedig a súlyvonal-csípőközpont távolság vetülete, amely normális anatómiai viszonyok mellett $3: 1$ arányban viszonyul egymáshoz. ${ }^{7}$ A kétkarú emelő forgáspontja maga a csípőízület. A számítás alapján egy 70 kg-os ember esetén például a csípőre 280 kg terhelés jut. Könnyü belátni, hogy megváltozott, a normálistól eltérő anatomiájú csípőizület esetén ez a terhelés a sokszorosára is emelkedhet, ami elhasználódásos (degeneratív) folyamatok kialakulásához vezet. ${ }^{8}$

\section{4. Állás és járás}

Állás közben a test látszólagos nyugalomban van, a két alsó végtagra támaszkodik, a talpakra helyezve a test súlyát. Nyugodt testtartás mellett a súlyvonal (2. ábra) a külső hallójárat közepétől indul ki, majd a váll-, csípő- és térdízületen keresztül éri el a támaszkodási felszínt. Ennek ismerete azért fontos, mert az ettől eltérő súlyvonal megjelenése a normálishoz képest nagyobb izommunkát igényel. Tulajdonképpen álló testhelyzetben az izommüködés stabilizációja következtében a testünk állandó, kis mértékü mozgást végez izommunka felhasználásával. Az izommunka testtartástól függő tényező. Katonás vigyázzállás esetén mintegy $20 \%$-kal több energia szükséges,

Damien P. Byrne - Kevin J. Mulhall - Joseph F. Baker: Anatomy and Biomechanics of the Hip. The Open Sports Medicine Journal, 4. (2010), 1. 51-57.

8 Szendrői (szerk.) (2005): i. m. 342. 
mint könnyed testhelyzet felvétele esetén, sőt ernyedt testhelyzetben is körülbelül 10\%-os energiafelhasználás történik az állás biztosítása céljából. ${ }^{9}$

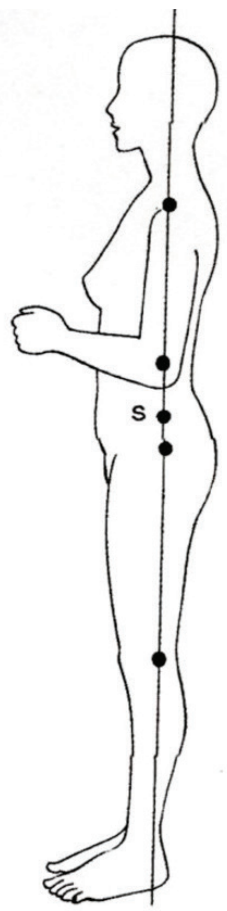

2. ábra

A test normál súlyvonala állás közben Forrás: Szendrői (szerk.) (2005): i. m. 28.

S: súlypont

Járásunk teszi lehetővé, hogy helyváltoztató életmódunk legyen, amely folyamán az alsó végtagok váltakozó mozgása révén mozdul el a test a kívánt irányba. Alsó végtagjaink mellett a fej, a törzs, a felső végtagok összehangolt mozgása is szerepet játszik a járástípus kialakulásában. Nagy vonalakban elmondható, hogy a járás mindig a stabil és stabilitását vesztett egyensúlyi helyzetek váltakozása révén ölt formát. A járás alapja a lépés, amelyet, ha objektíven szeretnénk leírni, akkor a lépéshosszt és a lépésidőtartamot kell használjuk annak jellemzésére. A lépés két szakaszból áll: támaszkodási és lengési fázis. A ciklusidő hozzávetőleg $60 \%$ támaszkodási és $40 \%$ lengési időre osztódik fel. A három szakaszra bontható támaszkodási fázis a következő folyamatokból tevődik össze: saroktámasz, gördítés, elrugaszkodás. A lengési fázis végtagrövidülés és végtaghosszabbodás szakaszaiból áll. A járás során egy lépés alatt két kettős támasz és két egyes támasz van, azaz kétszer van olyan periódus,

9 Szendrői (szerk.) (2005): i. m. 27-29. 
amelynél az egyik végtag még, a másik pedig már támaszkodik. A későbbiek megértése szempontjából fontos, hogy gyors járásnál a kettős támasz időtartama jelentősen lecsökken, futásnál pedig megszúnik. Járás során, annak megfelelő kivitelezésénél a medence, a csípőízület, a térdízület és a bokaízület is szerepet játszik. Mindenre kiterjedően ezen ízületek vizsgálata meghaladja a cikk témáját, de a csípőízület vonatkozásában szükséges kitérni e biomechanikai összefüggésekre a könnyebb érthetőség kedvéért. ${ }^{10}$

A csípőízületben saroktámasznál 30-40 fokos flexio van jelen, majd fokozatosan extendálódik az ízület, amelynek végén teljes extensio következik be az elrugaszkodási fázis előtt, majd fokozatos flexio kezdődik, a saroktámaszig. A térdízületben a flexio fokozatosan extensióba megy át, majd a végextensiónál, amely a másik oldali láb saroktámaszát jelenti egyben, gyors flexio következik ismét. ${ }^{11}$

Ha megértettük a járást és állást mint alapvető alsó végtagi mozgást, akkor számos további érdekes szempont alapján vizsgálhatjuk, boncolgathatjuk a folyamatot. Születtek tanulmányok, amelyekben a szerzők többek között a nemi különbségekből adódó eltéréseket is vizsgálták. Azt találták, hogy a női láb - általában - kisebb volta miatt a sarok-lábközép-lábujj érintkezése a járás állási fázisában a talaj-láb érintkezési idő összehasonlításában eltérő a férfi lábbal összehasonlítva. ${ }^{12}$

Az ízületek mozgását az azokat mozgató izmok biztosítják, így érdemes kitérni a csípőízület mozgását véghez vivő izmok működésére is. A csípőízületben a gluteus maximus (a nagy farizom) a támaszkodási fázis elején működik, az abductorok működése szükséges a medence stabilizálásához. Ha a test súlypontja a lengő oldal felett van, akkor az abductoroknak kifejezetten nagy erőre van szükségük a medence stabilitásának megőrzéséhez, és ellentétesen: ha a támaszkodó oldal felett van a törzs súlypontja, akkor kisebb izomerő is elég a medence stabilizálásához. Kettős támasznál egyenletesen oszlik el a két csípőízület felett a törzs súlya. Az adductorok a sarok támaszkodásánál és az elrugaszkodás után müködnek. A flexorok a lengési szakasz kezdetén aktívak. A térdízületben a m. quadriceps feladata a sarokra érést követően kezdődik, majd nincs aktivitása, amikor a támaszkodó végtag felett van a testsúly, azonban ismét aktiválódik a támaszkodási fázis végén. A comb flexorok aktivitása a lengőfázis végén és a támaszkodási fázis elején figyelhető meg. ${ }^{13}$

A csípőízületre ható erők a következőképpen alakulnak, ha a támaszkodó és a lengő végtag felett van a test súlypontja. A csípőízületre, annak szövetére, különösképpen a porc és a porc alatti csontszövetre ható mechanikai faktorok mind hatással vannak az ízületre (3. ábra).

10 Szendrői (szerk.) (2005): i. m. 29-30.

11 Szendröi (szerk.) (2005): i. m. 30.

12 Richard C. Nelson - Chaunsey A. Morehouse (szerk.): Biomechanics IV. Baltimore, Maryland USA, Macmillan Education, 1974. 85-90.

13 Nelson-Morehouse (szerk.) (1974): i. m. 30-31. 

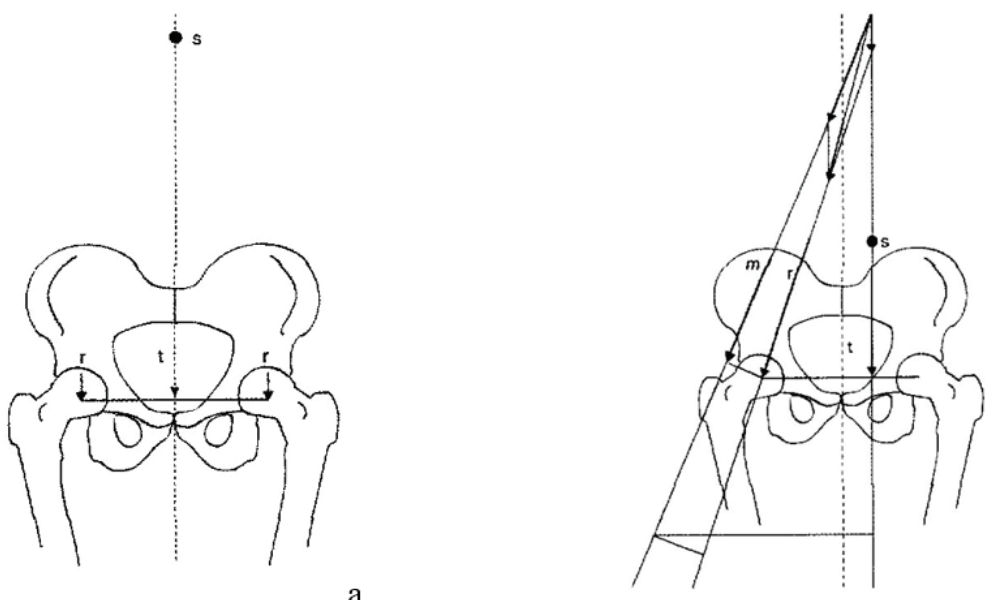

a

b

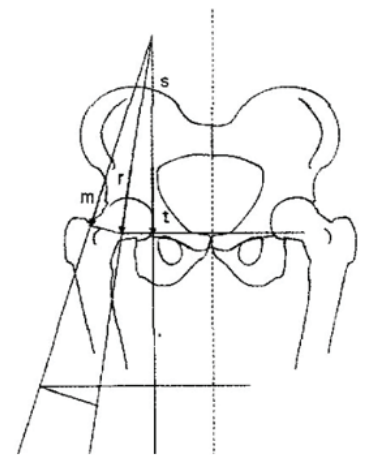

c

3. ábra

Súlyeloszlási viszonyok

Forrás: Szendrői M (szerk.) (2005): i. m. 31.

a: a test súlyának eloszlása kettős alátámasztás esetén

b: a nyomóerö, ha a test súlypontja a lengő végtag felett van

c: a nyomóerő, ha a test súlypontja a támaszkodó végtag felett van

S: a törzs súlypontja; t: testsúly; r: a femur fejre ható nyomás; m: abductor izomerö. b: a lengő oldal felett ható testsúly a hosszú erőkar miatt nagyobb abductor izomerőt kíván a medence lebillenésének megakadályozása érdekében. c: a támaszkodó végtag felett ható testsúly a megrövidült erőkar miatt kisebb abductor izomerőt tesz szükségessé a medence stabilitásához. Járás és egy lábon állás közben hasonlóan alakulnak ezek az erők és erőkarok.

Az ízület alakját legjobban a gömbízületi forma jellemzi, ahol a combcsont feje kongruens az ízületi vápával. Röntgenfilmen könnyü a combcsont fejének kontúrját felismerni, amelynek középpontja egyben az ízület rotációs központja is (4. ábra). A röntgenen látható ízületi vápa és fej kontúrja közti területen található a porcszövet, amely terület felezéspontjában van a tényleges ízületi felszín. ${ }^{14}$

14 Paul Brinckmann - Wolfgang Frobin - Gunnar Leivseth: Musculoskeletal Biomechanics. Stuttgart - New York, Thieme, 2002. 78-79. 
Zsákai Zsolt: Az emberi csípő, térd és gerinc biomechanikai jellemzői...

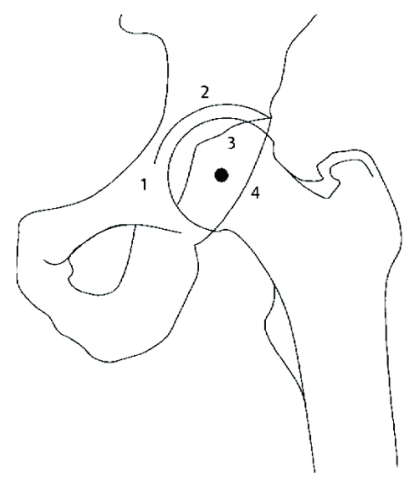

4. ábra

A röntgenfilmen fellelhetö csípöizületi kontúrok

Forrás: Brinckmann-Frobin-Leivseth (2002): i. m. 79.

1: a csontos femur fej; 2: az acetabulum cranialis conturja; 3: az acetabulum elülső pereme; 4: az acetabulum hátulsó pereme

A terhelö felszín megközelítöleg egy félgömbnek hat a modell alapján, azonban az ízületi vápa peremének alakja miatt igazából kisebb, mint egy félgömb. Kummer, vizsgálata alapján, azt találta, hogy a félhold alakú terhelési felszín szögben kifejezve kétszerese az erővektor és a vápa külső pereme közti szögnek ${ }^{15}$ (5. ábra).

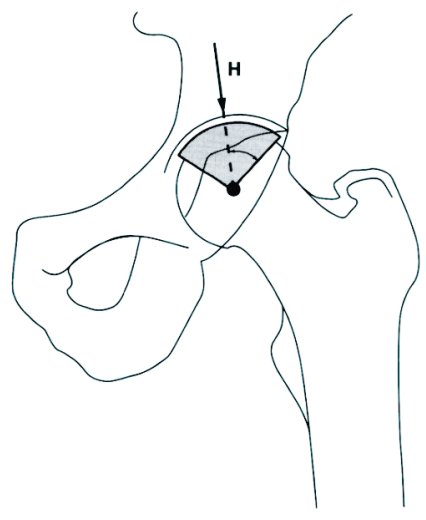

5. ábra

A félhold alakú terhelési felszín kivetülése

Forrás: Brinckmann-Frobin-Leivseth (2002): i. m. 80.

H: ez a nyíl mutatja meg a nyomóerő kivetülési pontját. A sötétszürke rész mutatja a teherviselő felszín kivetülését, amely az acetabulum lateralis sarka és a nyomóerő kivetülési pontja közti távolság duplája.

15 Benno Kummer: Die Beanschpruchung des menschlichen Hüftgelenks. I Allgemeinen Problematik. Zeitschrift für Anatomie und Entwicklungsgeschichte, 127. (1968), 4. 277-285. 
Brinckmann és munkatársai kimutatták, hogy a csípőízületben fellépő nyomás a 6. ábrán látható helyen terheli az ízületet. ${ }^{16}$ A nyomási maximum pedig, a vápa külső peremének elhelyezkedésétől, a terhelési erő nagyságától, a combcsont fejének sugarától, valamint a terhelési erővonal és a perem relatív elhelyezkedésétől függően valahol a perem és a nyomási erő vektorának kivetülési pontja közt helyezkedik el. ${ }^{17}$

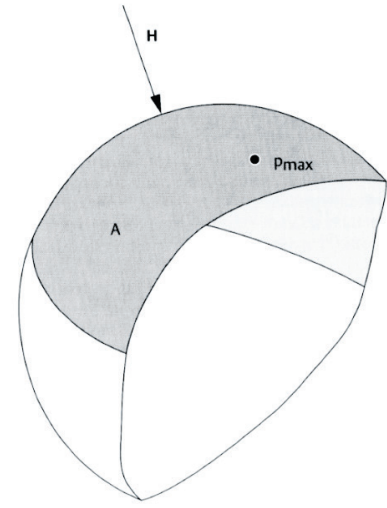

6. ábra

A terhelési felszín sematikus ábrája a maximális nyomási pont feltüntetésével Forrás: Brinckmann-Frobin-Leivseth (2002): i. m. 80.

A: terhelési felszín; $\mathrm{H}$ : a terhelési vektor; $\mathrm{P}_{\max }$ : a maximális nyomáspont helye. Látható, hogy a maximális nyomáspont elhelyezkedése a nyomóerő kivetülési pontjától lateralis irányba az acetabulum felső pereme felé tolódik.

Szintén Brinckmann és munkatársai munkájából tudjuk, hogy különböző csípőízületi fedettség esetén máshol és más erőnagysággal van jelen a porcra ható nyomás. Az emberi csípőízületre jellemző helyre eső maximális nyomást mutató pont a $130^{\circ}$-os fedettségnél látható. Természetesen ezt a $180^{\circ}$-os fedettséggel összevetve érdemes vizsgálni, ahol a félgömb centrumában hat a maximális nyomás. További értékeket vizsgálva, a fedettségi szöget csökkentve azt kapták, hogy $110^{\circ}$-nál már konkrétan a vápa peremére helyeződik át ez a nyomásmaximum. ${ }^{18}$ Ez pedig nagyon fontos szerepet tölt be a csípőízület terhelése és terhelhetősége szempontjából. Ebből könnyü következtetni arra, hogy nem megfelelő fedettség esetén a csípőízületre jellemző nyomáspont eltérő lehet, ami az ott lévő porc károsodását felgyorsíthatja, ezzel degeneratív betegségek talaját képezheti, panaszok megjelenését indukálhatja.

16 Paul Brinckmann - Wolfgang Frobin - E. Hierholzer: Stress on the articular surface of the hip joint in healthy adults and persons with idiopathic osteoarthrosis of the hip joint. Journal of Biomechanics, 14. (1981), 3. 149156.

17 Brinckmann-Frobin-Leivseth (2002): i. m. 81.

18 Paul Brinckmann - Wolfgang Frobin - E. Hierholzer: Belastete Gelenkflache und Beanschpruchung des Hüftgelenks. Zeitschrift für Orthopädie und Unfallchirurgie, 118. (1980), 1. 107-115. 


\section{A csípöízület túlterhelése a szakirodalomban}

A biomechanikai és anatómiai összefüggéseket megismerve és megértve nyilvánvalóbbá válik azon folyamatok fontossága, amelyek a csípőben túlterhelést okozhatnak.

A csípöízületben számos betegséget fel lehet sorolni, amelyek a normál biomechanikai viszonyokat megváltoztatva átalakítják a terhelést, túlterhelve az ízületet. A látványos betegségek közt, mint a balesetek következtében kialakult anatómiai eltérések, gyulladások okozta deformációkon, daganatok csontot és ízületet érintő roncsolásán kívül, vannak kevésbé nyilvánvaló és látványos betegségek is. Ilyenek - a teljesség igénye nélkül - például a gyermekkori combfej-növekedési fuga elcsúszása (epiphyseolisis capitis femoris) és a csípőizületi beütődéses kórkép (impingement coxae), amely utóbbi tudományos vizsgálatom tárgyát is képezi.

Az impingement coxae három formájának - a $C_{A M}{ }^{19}$ a PINZER ${ }^{20}$ és a KEVERT ${ }^{21}$ típus - jelenléte hagyományos (anteroposterior) röntgenfelvétellel is megállapítható, speciális röntgen jelek, mint az ülötövis (spina ischiadica) jel, ${ }^{22}$ a hátsó fal jel, ${ }^{23}$ a kereszteződési tünet, ${ }^{24}$ az ellapult fej és a pisztolymarkolat deformitások ${ }^{25}$ alapján. A betegség fontosságát az adja, hogy az átlag populatióban vizsgálva magas arányban találtuk ezen elváltozás valamelyik formáját azoknál, akiknél csípőkopás miatt protézismütét vált indokolttá. Az esetek $88 \%$-ában jelen voltak a betegségre jellemző röntgentünetek, míg a kontrollcsoportnál ez csupán 8,8\%-nak adódott. ${ }^{26} \mathrm{~A}$ már említett kutatásom egyik hipotézise, hogy az aktív szolgálatot teljesítő katonák esetén is magas arányban találunk ilyen elváltozást, amely a megnövekedett terheléssel együtt szerepet játszik a panaszok kialakulásában. A nemzetközi irodalom áttekintése során megerősítést találtam feltevésem igazolhatóságára, kutatásom létjogosultságára.

Harrison és munkatársai írták le először a porc degeneratív elváltozását már kezdődő porckopásban (arthrosis) is. ${ }^{27}$ Pawels vizsgálatai után megállapította, hogy az ízületi nyomásviszonyok - különösen a vápa peremének környékén - nagy szerepet játszanak az ízület arthrosisának kialakulása szempontjából. ${ }^{28}$ Radin és munkatársai kimutatták, hogy az izületi túlterhelés miatt első lépcsőben a porc alatti trabecularis csont elváltozása következik be, a megjelenő mikrotörések (microfractura) miatt, amelynek gyógyulási folyamatai ugyanezt a régiót megerősítik. ${ }^{29}$

A combfej-nyak átmenetben lévő felrakódások következtében kialakult forma.

Az ízületi ajakporc (labrum) elmeszesedése, csontosodása, károsodása következtében kialakult forma.

A fenti kettő együttes megjelenését magában hordozó forma.

22 A spina ischiadica (ülötövis, az ülőcsont egy nyúlványa) háromszög alakban bevetül a medencebemenetbe.

23 Az ízületi perem hátulsó része, a hátulsó fal vonala, a combfej középpontjához viszonyítva medialisan helyezkedik el.

24 Az ízületi perem elülső falának vonala fejvégi helyzetben (cranialisan), a hátulsó fal vonalához képest kívülre esik, míg a farokvég részen (caudalisan) belülre, ezáltal a röntgenen egymást keresztezve vetülnek.

25 A combcsonti fej-nyak átmenet anatómiai görbülete kiegyenesedik a csontos felrakódások következtében.

26 Zsákai Zsolt et al.: Primer arthrosisok retrospectív vizsgálata anteroposterior medence felvételek alapján. - A Femoroacetabularis impingement okozta arthrosis. Magyar Radiológia, 2015. július 11.

27 M. H. M. Harrison - F. Schajowicz - J. Trueta: Osteoarthritis of the hip: a study of the nature and evolution of the disease. The Journal of Bone and Joint Surgery, 35B. (1953), 4. 598-625.

28 Friedrich Pauwels: Biomechanics of the Locomotor Apparatus. New York, Springer, 1980.

29 Eric L. Radin - Igor L. Paul - Marc J. Tolkoff: Subchondral bone changes in patients with early degenerative joint disease. Arthritis \& Rheumatology, 13. (1970), 4. 400-405; Eric L. Radin et al.: Response of joints to impact loading - III: Relationship between trabecular microfractures and cartilage degeneration. Journal of Biomechanics, 6. (1973), 1. 51-57. 
Látható, hogy az ízületi nyomásviszony és annak változása milyen negatív hatású az ízületekre, köztük a csípőízületre is. Ennek megértése fontos, hiszen megnövekedett terhelés esetén komolyan figyelembe kell vegyük azokat az elváltozásokat, amelyek vagy az anatómiai, vagy a biomechanikai viszonyok miatt jelen vannak az egyénben, és a panaszok kialakulásában is nagy szerepet játszhatnak.

Az aktív katonai szolgálatot teljesítők vonatkozásában a mozgásszervi megbetegedések vizsgálatát elemző hazai szakirodalom nem áll rendelkezésre. Nemzetközi irodalomban természetesen találhatunk ilyen jellegű vizsgálatokat, de még azok közt is nagy számban vannak jelen az olyan tanulmányok, amelyek analógiát vonnak az aktív katonai szolgálat és az egyéb fokozott megterheléssel járó populatiók, mint például a professzionális sportolók megterhelése közt. Kizárólagosan a katonai állományt vizsgáló nemzetközi írás lényegesen kevesebb számban található, és azok hivatkozásaiban is fellelhető a fenti analógia.

Cameron és munkatársai az Amerikai Egyesült Államok Hadseregének aktív állományában előforduló degeneratív ízületi kopás incidenciáját vizsgálták. Azt találták - nagy esetszámot vizsgálva -, hogy a degeneratív ízületi kopások nagyobb százalékban fordultak elő az aktív katonai állományban, mint a vizsgálat során összehasonlított átlag populatióban. Tanulmányuk szerint a megnövekedett kor, az aktív katonai szolgálat, a női nem, az afroamerikai rassz mind összefüggésben van az osteoarthritis megnövekedett incidenciájával. ${ }^{30}$ Scher és munkatársai szintén leírták, hogy az aktív szolgálatot teljesítő állományban a női nem, az afroamerikai rassz, a 40 év vagy annál magasabb életkor, a rangidős tiszti rang és a katonai szolgálat, különösen a haditengerészet, tengerészgyalogság állományában, jelent nagyobb rizikótényezőt mozgásszervi betegségek viszonylatában. ${ }^{31}$ Jochimsen és munkatársai szerint a veterán katonai populatiónál kialakult arthrosis nagyobb százalékban azonosítható a csípő ütközéses kórképe következményének, mint a civil lakosság körében. ${ }^{32}$ Javasolták további vizsgálatok elvégzését, amelyekkel azt vizsgálják, hogy vajon az időben elvégzett arthroscópos beavatkozással megelőzhetővé, vagy késleltethetővé válik-e az aktív populatióban az arthrosis kialakulása, illetve a kórkép kifejlődése.

Az irodalmi utalásokban több helyen feltűnik az arthroscopia (ízületi tükrözés) mint mütéti technika fogalma. Magyarázatként szeretném kifejteni, hogy ezen eljárásnak napjainkban a diagnosztikai értékén kívül jelentős terápiás szerepe is van, mert a technika alkalmazása során számos elváltozást definitíve kezelni tudunk. Néhány ilyen lehetőség: a levált porc eltávolítása, múvi microfractura ${ }^{33}$ elvégzése, labrum (ajakporc) visszavarrása. Az arthroscópos mütét előnye többek közt a szervezet és a szövetek számára fellépő, jelentősen kisebb megterhelés, a szövődmények kockázatának

30 Kenneth L. Cameron et al.: Incidence of Physician-Diagnosed Osteoarthritis Among Active Duty United States Military Service Members. Arthritis \& Rheumatology, 63. (2011), 10. 2974-2982.

31 Danielle L. Scher et al.: The Incidence of Primary Hip Osteoarthritis in Active Duty US Military Servicemembers. Arthritis \& Rheumatism, 61. (2009), 4. 468-475.

32 Kate $\mathrm{N}$. Jochimsen et al.: Femoroacetabular impingement is more common in military veterans with end-stage hip osteoarthritis than civilian patients: A retrospective case control study. Military Medical Research, 6. (2019), 1. 27.

33 Microfractura során a körülhatárolt porcdefektus területén lévő csontkéregállomány átütése történik, amelynek következménye, hogy a kiszivárgó csontvelőben lévő őssejtek képesek lehetnek rostosporc kialakítására. 
csökkenése, a rehabilitációs idő lerövidülése, aminek pedig következménye az újbóli hadrendbe állíthatóság várakozási idejének csökkenése.

Blank és munkatársai a csípőtájéki fájdalmakat vizsgálva állapították meg, hogy az aktív katonai szolgálat, a női nemhez való tartozás és a magasabb életkor megnövekedett rizikófaktort jelentenek a degeneratív csípőtájéki fájdalom kialakulásában. ${ }^{34}$ Gwatmey és munkatársai a csípő impingement és a túlterheléses csípőbetegségek megnövekedett előfordulását írja le az aktív katonai állományban. Terápiás lehetőségként említi a csípőizület tükrözését mint definitív megoldást ezen esetekben, amely után a csípő terhelhetősége javul és a szolgálat ismét felvehetővé válik. ${ }^{35}$ Dutton és szerzőtársai is azt jelentették, hogy a csípő arthroscopia effektív megoldásnak számít az aktív, a csípőízület bizonyos megbetegedéseivel küzdő katonai állomány esetében, valamint a mütét ráadásul lehetővé teszi a szolgálat további folytatását. ${ }^{36}$ Yoo és munkatársai egy kisebb esetszámot vizsgáló tanulmányban azt közölték, hogy a csípő arthroscopia eredményessége a katonai populatiót vizsgálva hasonló, mint a civil populatio esetén. A kórházban eltöltött időt többnek találták a civil lakosság kórházban töltött idejéhez képest, azonban az aktivitáshoz való teljes visszatérés hasonlónak mutatkozott. ${ }^{37}$ Kuhn és munkatársai azt vizsgálták, hogy a csípőízületi vápa biomechanikai eltérése esetén milyen valószínúséggel alakulnak ki panaszok az érintett csípőben, valamint hogy ez milyen relációban van az ütődéses combnyaktöréssel. Azt közölték, hogy nagyobb százalékban volt jelen az eltérés a stresszes törést elszenvedő katonák esetén. ${ }^{38}$ Hasset és szerzőtársai más szempontból is elemezték a bevetések utáni fájdalom mint tünet kialakulását. Úgy találták, hogy alacsony kedélyállapoti szint esetén nagyobb valószínűséggel jelentek meg új panaszként a mozgásszervi fájdalom tünetei ${ }^{39} \mathrm{~A}$ kiképzések és bevetések közben fellépő biomechanikai hatásokon kívül a speciális eszköz és felszerelés is okozhat mozgásszervi panaszokat, ezért ezek állandó felülvizsgálata és fejlesztése szükséges. A nemzetközi irodalomban megtalálható Lenton és munkatársai közleménye, amelyben a katonai testpáncél viselésével kapcsolatos kutatásaikat összegezték. Azt találták, hogy a testpáncél viselése, használata, nem megfelelő kialakítása növelheti a mozgásszervi sérülések valószínűségét. ${ }^{40}$

Ezen irodalmi példák is jól mutatják, hogy milyen jelentősége van a mozgásszervi irányú szürésnek és állandó monitorozásnak az aktív állomány esetében. Az irodalmi áttekintésben felhozott közlemények példaként szolgálnak olyan, más szerzőktől

34 Elizabeth Blank et al.: Incidence of Greater Trochanteric Pain Syndrome in Active Duty US Military Servicemembers. Orthopedics, 35. (2012), 7. 1022-1027.

35 F. Winston Gwathmey Jr. - Warren R. Kadrmas: Intra-articular Hip Disorders in the Military Population: Evaluation and Management. Clinics in Sports Medicine, 33. (2014), 4. 655-674.

36 Jason R. Dutton et al.: The Success of Hip Arthroscopy in an Active Duty Population. Arthroscopy: The Journal of Arthroscopic and Related Surgery, 32. (2016), 11. 2251-2258.

37 Jun-Il Yoo et al.: Outcomes of Hip Arthroscopy in a Military Population Are Similar to Those in the Civilian Population: Matched Paired Analysis at 2 Years. Arthroscopy: The Journal of Arthroscopic and Related Surgery, 34. (2018), 7. 2096-2101.

38 Kevin M. Kuhn et al.: Acetabular Retroversion in Military Recruits with Femoral Neck Stress Fractures. Clinical Orthopedic Related Research, 468. (2010), 3. 846-851.

39 Afton L. Hassett et al.: Association Between Predeployment Optimism and Onset of Postdeployment Pain in US Army Soldiers. JAMA Network Open, 2. (2019), 2. e188076.

40 Gavin Lenton et al.: The Effects of Military Body Armour on Trunk and Hip Kinematics During Performance of Manual Handling Tasks. Ergonomics, 59. (2016), 6. 806-812. 
eredő közleményekre, amelyek kutatásom szükségességét és gyakorlati alkalmazhatóságát bizonyítják. Tudomásom szerint kutatásom elsőként fogja feltárni, elemezni az aktív, szolgálatot teljesítő állomány hazai viszonylatban előforduló mozgásszervi megbetegedéseit, különös tekintettel a csípő bizonyos rendellenességeire.

\section{Felhasznált irodalom}

Blank, Elizabeth - Brett D. Owens - Robert Burks - Philip J. Belmont: Incidence of Greater Trochanteric Pain Syndrome in Active Duty US Military Servicemembers. Orthopedics, 35. (2012), 7. 1022-1027. Online: https://doi.org/10.3928/0147744720120621-14

Brinckmann, Paul - Wolfgang Frobin - E. Hierholzer: Belastete Gelenkflache und Beanschpruchung des Hüftgelenks. Zeitschrift für Orthop und Unfallchirurgie, 118. (1980), 1. 107-115. Online: https://doi.org/10.1055/s-2008-1051478

Brinckmann, Paul - Wolfgang Frobin - E. Hierholzer: Stress on the articular surface of the hip joint in healthy adults and persons with idiopathic osteoarthrosis of the hip joint. Journal of Biomechanics, 14. (1981), 3. 149-156. Online: https:// doi.org/10.1016/0021-9290(81)90021-X

Brinckmann, Paul - Wolfgang Frobin - Gunnar Leivseth: Musculoskeletal Biomechanics. Stuttgart - New York, Thieme, 2002.

Byrne, Damien P. - Kevin J. Mulhall - Joseph F. Baker: Anatomy and Biomechanics of the Hip. The Open Sports Medicine Journal, 4. (2010), 1. 51-57. Online:: https:// doi.org/10.2174/1874387001004010051

Cameron, Kenneth L. - Mark S. Hsiao - Brett D. Owens - Robert Burks - Steven J. Svoboda: Incidence of Physician-Diagnosed Osteoarthritis Among Active Duty United States Military Service Members. Arthritis \& Rheumatology, 63. (2011), 10. 2974-2982. Online: https://doi.org/10.1002/art.30498

Dutton, Jason R. - Nicholas A. Kusnezov - Joseph T. Lanzi - E'Stephan J. Garcia - Mark P. Pallis: The Success of Hip Arthroscopy in an Active Duty Population. Arthroscopy: The Journal of Arthroscopic and Related Surgery, 32. (2016), 11. 2251-2258. Online: https://doi.org/10.1016/j.arthro.2016.05.042

Gwathmey, F. Winston Jr. - Warren R. Kadrmas: Intra-articular Hip Disorders in the Military Population: Evaluation and Management. Clinics in Sports Medicine, 33. (2014), 4. 655-674. Online: https://doi.org/10.1016/j.csm.2014.06.013

Harrison, M. H. M. - F. Schajowicz - J. Trueta: Osteoarthritis of the hip: a study of the nature and evolution of the disease. The Journal of Bone and Joint Surgery, 35B. (1953), 4. 598-625. Online: https://doi.org/10.1302/0301-620X.35B4.598 Hassett, Afton L. - Joseph A. Fisher - Loryana L. Vie - Whitney L. Kelley - Daniel J. Clauw - Martin E. P. Seligman: Association Between Predeployment Optimism and Onset of Postdeployment Pain in US Army Soldiers. JAMA Network Open, 2. (2019), 2. e188076. Online: https://doi.org/10.1001/jamanetworkopen.2018.8076

Jochimsen, Kate N. - Cale A. Jacobs - Stephen T. Duncan: Femoroacetabular impingement is more common in military veterans with end-stage hip osteoarthritis 
than civilian patients: a retrospective case control study. Military Medical Research, 6. (2019), 1. 27. Online: https://doi.org/10.1186/s40779-019-0218-5

Kuhn, Kevin M. - Anthony I. Riccio - Nelson S. Saldua - Jeffrey Cassidy: Acetabular

Retroversion in Military Recruits with Femoral Neck Stress Fractures. Clinical Orthopedic Related Research, 468. (2010), 3. 846-851. Online: https://doi. org/10.1007/s11999-009-0969-5

Kummer, Benno: Die Beanschpruchung des menschlichen Hüftgelenks. I Allgemeinen Problematik. Zeitschrift für Anatomie und Entwicklungsgeschichte, 127. (1968), 4. 277-285. Online: https://doi.org/10.1007/BF00524417

Lenton, Gavin - Brad Aisbett - Daniel Neesham-Smith - Alvaro Carvajal - Kevin Netto: The Effects of Military Body Armour on Trunk and Hip Kinematics During Performance of Manual Handling Tasks. Ergonomics, 59. (2016), 6. 806-812. Online: https://doi.org/10.1080/00140139.2015.1092589

Nelson, Richard C. - Chaunsey A. Morehouse (szerk.): Biomechanics IV. Baltimore, Maryland USA, Macmillan Education, 1974.

Pauwels, Friedrich: Biomechanics of the Locomotor Apparatus. New York, Springer, 1980. Online: https://doi.org/10.1007/978-3-642-67138-8

Radin, Eric L. - Howard G. Parker - James W. Pugh - Robert S. Steinberg - Igor L. Paul - Robert M. Rose: Response of joints to impact loading - III: Relationship between trabecular microfractures and cartilage degeneration. Journal of Biomechanics, 6. (1973), 1. 51-57. Online: https://doi.org/10.1016/0021-9290(73)90037-7

Radin, Eric L. - Igor L. Paul - Marc J. Tolkoff: Subchondral bone changes in patients with early degenerative joint disease. Arthritis \& Rheumatology, 13. (1970), 4. 400-405. Online: https://doi.org/10.1002/art.1780130406

Scher, Danielle L. - Philip J. Belmont - Sally Mountcastle - Brett D. Owens: The Incidence of Primary Hip Osteoarthritis in Active Duty US Military Servicemembers. Arthritis \& Rheumatism, 61. (2009), 4. 468-475. Online: https://doi.org/10.1002/ art.24429

Szendrői Miklós (szerk.): Ortopédia. Budapest, Semmelweis, 2005.

Szentágothai János - Réthelyi Miklós: Funkcionális anatómia 1 kötet. Budapest, Medicina-Semmelweis, 1996.

Yoo, Jun-Il - Tae-Ho Lee - Jae-Yoon Kim - Jae-Hyung Kim - Yong-Chan Ha: Outcomes of Hip Arthroscopy in a Military Population Are Similar to Those in the Civilian Population: Matched Paired Analysis at 2 Years. Arthroscopy: The Journal of Arthroscopic and Related Surgery, 34. (2018), 7. 2096-2101. Online: https:// doi.org/10.1016/j.arthro.2018.02.015

Zsákai Zsolt - Papp Miklós - Huszanyik István - Rácz Olivér - Molnár Péter - Károlyi Zoltán - Róde László: Primer arthrosisok retrospectív vizsgálata anteroposterior medence felvételek alapján. - A Femoroacetabularis impingement okozta arthrosis. MagyarRadiológia, 2015. július 11. Online: https://radiologia.hu/kozossegek/kategoria/msk/primer-artrozisok-retrospektiv-vizsgalata-anterio poszterior-_15430362 